\title{
Mediatization and the changing authority of religion
}

Hjarvard, Stig

Published in:

Media, Culture \& Society

DOI:

10.1177/0163443715615412

Publication date:

2016

Document version

Peer reviewed version

Citation for published version (APA):

Hjarvard, S. (2016). Mediatization and the changing authority of religion. Media, Culture \& Society, 38(1), 8-17. https://doi.org/10.1177/0163443715615412 
Preprint of article published in Media, Culture \& Society, 2016, Vol. 38(1) 8-17.

http://mcs.sagepub.com/content/38/1/8.full.pdf+html

Special Issue: Media and Religion

DOI: $10.1177 / 0163443715615412$

\title{
Mediatization and the changing authority of religion
}

\author{
Stig Hjarvard \\ University of Copenhagen, Denmark \\ stig@hum.ku.dk
}

\begin{abstract}
Both mass media and social network media have become important sources of information and experiences about religion. The mediatization of religion challenges the authority of existing religious organizations at the same time as various media allow for new forms of religious beliefs and practices to appear. Media provide a backdrop of 'banal religion', comprized of a bricolage of representations and practices without any necessary connection to specific, organized forms of religion. Max Weber's typology of authority may provide a partial understanding of the changing authority of religion in contemporary society, but the media also allow other forms of authority to emerge. In a mediatized environment, religious legitimacy is not only produced by means of tradition and charisma but also rests upon voluntary acceptance by the individual and references to popular media culture.
\end{abstract}

\section{Keywords}

Authority, banal religion, mediatization, Nordic countries, popular culture, secularization.

\section{Introduction}

Religion has become more publicly visible over the past decades in several parts of the world, including the predominantly secular Nordic countries, and has acquired a continuous presence on various political and cultural agendas. The increased visibility is not least due to the presence of religion in the media, including news media, entertainment media, and social network media. For some scholars of religion, the growing public 
visibility has been used to claim a resurgence of religious belief in general and to denounce the idea of secularization in particular. Peter Berger, himself once a proponent of secularization theory, has stated that the world is "as furiously religious as it ever was, and in some places more so than ever. This means that a whole body of literature by historians and social scientists loosely labeled 'secularization theory' is essentially mistaken" (Berger, 1999: 2).

In this article, I will pursue a more cautious line of reasoning and address the role of media in the growing visibility of religion. In short, I will argue that the visibility of religion is in part a reflection of a general mediatization of religion through which religious beliefs, agency, and symbols are becoming influenced by the workings of various media. There are, of course, many other and in some respects more important reasons for the increased presence of religion in modern societies, such as global migration, politicization of religious organizations, and the international war on terror. But the presence of religion in the media is not just a mirror of a religious reality 'outside' the media. It is also an outcome of a complex set of processes in which the importance of religion and particular religious beliefs and actions are contested as well as reasserted, both in and by the media, at the same time as religion undergoes transformation through the very process of being mediated through various media. I will focus my attention on the question of to what extent and in what ways religious authority may undergo transformation in view of the general process of mediatization. The argument will rest primarily on research conducted in the Nordic countries (Hjarvard and Lövheim, 2012), in which the Protestant Lutheran church has historically occupied a dominant position and in which a wider range of religions have become visible in more recent times, not least Islam. Since my discussion of a changing religious authority is closely linked to the theoretical framework of mediatization, I will briefly introduce the main tenets of mediatization theory and the general characteristics of the mediatization of religion. This outline of the mediatization of religion will also serve as a reference for contributions by Knut Lundby, Mia Lövheim, and Günter Thomas in this issue of Media, Culture \& Society.

\section{Media and social change}

Across the range of different contributions to the field of mediatization studies, there seems to be general agreement that mediatization concerns the "interrelation processes between media change on the one hand and social and cultural change on the other" (Hepp et al., 2010: 223). Media and communication research has primarily been occupied with the study of 'mediation', i.e. the use of media for communicative practices, whereas the study of 'mediatization' is concerned with the long-term influence of media on cultural and social structures and agency. Applying an institutional perspective to mediatization, I have argued that by mediatization we understand the processes through which the various institutions of culture and society (family, politics, religion, etc.) become increasingly influenced by the media and their logics. By 'logics', we understand the media's various technological, aesthetic, and social modus operandi (Hjarvard 2013). From this perspective, mediatization entails a dual process by which the media have developed into a semi-independent societal institution at the same time as they have integrated into the workings of other institutions and become an indispensable part of 'doing family', 'doing politics', 'doing school', etc. The media are both 'out-there' in the wider society, constituting a public realm of shared experiences, and 'in-here' in the various social settings of civil society, as a kind of social tool that helps co-construct the routines and social relationships of ordinary life. 
From a sociological perspective, mediatization may be considered one of the general processes of modernity, on par with globalization, individualization, and urbanization: The media enable a continuous dynamic of disembedding social interaction from local and traditional contexts and re-embedding social interaction into larger and more modern settings. Social network media like Facebook, for instance, rely on sociable forms of communication typical of small groups in face-to-face contexts, yet social network media transform and reembed such communicative forms into larger networks of mediated 'friendships', which are influenced by various logics based on, for instance, media's technological and commercial considerations.

Mediatization may be considered a general process of modernity, but the ways in which this process is actually spelled out, the particular interactions between media developments and social developments, are variable and dependent on historical, geographical, and institutional context. The mediatization of politics may thus evolve differently in the USA compared to Scandinavia, and the influence of media on politics may be different from the influence of media on religion. As regards mediatization of religion, Meyrowitz's (1993) metaphorical distinctions between media as conduits, languages, and environments may be useful for differentiating between various dimensions of change (cf. Hjarvard, 2011, 2013). As conduits, media have increasingly become an important, if not the most important, source of information about religion in society. News media, social network media, and film and television drama have become resources for knowledge and experiences about religion while traditional religious organizations play a less significant role. The church and other religious actors may also use various media to seek to reach fellow believers and disseminate information about their religion, but the traditional religious media, genres, and texts (e.g. sermon, Bible, etc.) play a less central role for the circulation of information about religion. In effect, centralized control of information by religious organizations has become increasingly difficult both because of mass media's predominantly secular orientation towards this kind of information and as a result of the distributed, network-like character of various interactive media.

If we consider media as languages, i.e. particular modalities of representation and interaction, we must acknowledge that information about religion is molded in accordance with the demands of various popular media genres such as news, drama, consumer advice, and blogging. Journalistic news media play a significant role in framing religion and religious issues, and actors must usually comply with the demands of the journalistic news media in order to get attention. In practice, this implies that stories involving religion should be newsworthy, and religious actors need to conform to the role as a news source. In non-factual genres like computer games and feature films, religion has become one among many other cultural resources for storytelling, yet since mass media generally have no intention of preaching but are in the business of getting the audience's attention, religious messages are subordinated to this demand and have to comply with generic conventions. Religious organizations have - precisely because of these media conditions - often sought to develop their own media ventures like religious television stations and websites in order to project a version of religion that is less influenced by secular media.

Due to the spread of the internet and social network media, religious actors have acquired new modes of interacting with potential followers. This is perhaps especially true in the USA, where religious media have a long history and televangelism has played an important role in the rise of Pentecostalism. In the Nordic 
countries, religious mass media play a marginal role, but religious organizations are currently seeking to take advantage of digital media in various ways (Fischer-Nielsen, 2012). The use of both mass media and social network media influences how religion is represented as well as how church and followers interact with one another. In order to reach audiences and users through the various media, religious organizations and individuals must be sensitive to the demands and conventions of using the media in question. Placing the media at the center of a religious movement may involve reciprocal accommodation between media and religion to the extent that it makes no sense to distinguish between media and religious organization. This may be particularly true in North and South American contexts (cf. Hoover, 2006; Martino, 2013).

Finally, considering the media as environments, the media have acquired some of the societal functions that religious organizations had previously held a privileged position to perform. The media have become a significant arena for orchestrating public ritual events involving celebration as well as mourning. Mass media and social network media constitute national and cultural communities in various ways, allowing the individual to communicate with the wider community and experience a sense of belonging (Anderson, 1994; Carey, 1989). Both at a national and individual level, various forms of media provide moral orientation for the modern individual (Hjarvard, 2009) and emotional consolation in times of crisis. The media also encourage and facilitate various forms of worship behavior through fandom and celebrity culture. The functional and structural similarities between media and religion as environments do not imply that the media necessarily become religious when performing such functions, but it points to the fact that religious practices and functions such as ritual, idolatry, and worship may be transformed and re-contextualized in more secular domains.

\section{Authority and religion}

Studies of the interrelationships between media and religion suggest that the growing importance of various forms of media for the communication of religion potentially challenges the power relationships between established and newer forms of religions as well as between the religious domain and wider secular society. Meyer and Moors (2006) argue that the media's format, styles, and infrastructure "shape the specific modes by which religions go public, modes that are difficult to control by religious establishment. New media may both have a destabilizing and an enabling potential for established practices for religious mediation. In this sense, new media may resemble a Trojan horse" (Meyer and Moors, 2006: 11). Campbell (2007) examines the authority of religion online and documents how the challenges to authority concern different aspects (religious hierarchy, structure, ideology, and text) depending on the particular religion. Media may not only destabilize existing religious communication practices but also enable other practices to emerge, both inside and outside of established religious organizations and movements. In the following, I will discuss this issue through the concept of authority. If power is understood as the ability to influence actions and thoughts, authority occurs when the power of an entity (organization, person, object, rule, etc.) is recognized by others as effective and legitimate.

Following Weber's (1978) classic distinction between three ideal types of authority (traditional, charismatic, and rational-legal), religious authority may be said to particularly rest upon charismatic forms of authority since a recurrent characteristic of many religions is the set of divine abilities ascribed to religious individuals (e.g. 
prophets), objects (e.g. totem), or texts (e.g. the Bible). As Weber suggests, charismatic authority is difficult to sustain over time because it rests on the ability to maintain belief in extraordinary, individual powers. As a result, religion has often resorted to other forms of legitimization. The institutionalization of religion in the Nordic countries, i.e. the historical transformation of Christian communities into state churches, has bestowed Christianity with traditional as well as rational-legal forms of authority. Here, Christianity is also legitimized through its 'ancient history', the passing on of habits and rituals from one generation to the next, etc., as well as through its claims to bureaucratic and scientific rationality. Through institutionalization, the Christian church in the Nordic countries has become involved in various bureaucratic state functions such as taxation and registration of birth and death. The intellectualization of the profession of ministers through university-based theological education has provided a scientific aura to the interpretation of Christian texts.

Weber's three forms of authority continue to play a role in the legitimation of religion in contemporary, mediatized societies, and media may both reinforce and challenge them in various ways when engaging with religious affairs. American televangelism is, for instance, a clear example of the reassertion of charismatic religious authority in a modern media setting. In a Nordic context, the traditional authority of Christian ceremonies still plays a role in the media's ritualization of public events and national holidays. Weber's typology of authority also has explanatory power outside the realm of explicit and organized forms of religion. For instance, contemporary celebrity culture may to some extent be explained by the ability of media industries to construct charismatic forms of authority. The three forms of authority nevertheless seem insufficient to account for the ways in which religious imaginations and practices achieve authority through various forms of media and genres like blogs and television drama. One important aspect of this is, as Herbert (2011) suggests, that the ties between religious symbols and discourses and particular religious communities and institutions have loosened. We may therefore distinguish between, on the one hand, 'religion' as a specific community's particular set of beliefs and practices and, on the other hand, 'the religious' as a broader field of representations and practices disseminating across culture and society with no particular organizational foundation or demarcated set of followers (Herbert, 2011: 90; cf. Meyer and Moors, 2006). In order to understand how these diffuse forms of religion may achieve authority, we need to look beyond Weber's typology and consider how both mass media and social network media co-structure the formation of authority in new ways.

\section{Banal religion and the authority of the popular}

In my own work, I have sought to develop the notion of banal religion precisely in order to grasp this diffuse, less noticeable, yet pervasive circulation of religious imagery and practices in modern society. Inspired by Michael Billig's (1995) notion of 'banal nationalism', which he uses to describe the implicit, taken-for-granted, everyday representations and practices that create and affirm ideas and feelings of belonging to the nation, we may understand 'banal religion' as something different from particular religions with explicit and institutionalized symbols and practices. For Billig (1995), the nation is reproduced not only through overtly nationalistic symbols and practices - the 'waved flags' of nationalism - but also 'silently', through implicit cultural references as to what the nation is and to whom it belongs - 'the unwaved' flags of nationalism. In a similar way, contemporary ideas about what religion is or may be used for are informed by a bricolage of 
representations and practices without any necessary or close connection to specific, organized forms of religion. A television series like LOST (Clark, 2008) or a blog for young Muslim women (Lövheim, 2012) may become authoritative voices that evoke meanings about religion without being endorsed by official voices of particular religions. The notion of 'banal religion' does not imply that these forms of religion are inferior or less important than the explicit and organized forms of religion. On the contrary, such religious imaginations and practices are fundamental for any kind of religion, and in modern, media-saturated societies, they have become important as the cultural backdrop for everyday understanding of what religion is - partly at the expense of the organized forms of religions.

In the secular Nordic countries, popular media, including imported American popular culture, have become an important source of religious imaginations and discussions. As Endsjø and Lied (2011: 71) report, "In Norway in the 2000s, popular culture has become one of the most visible exponents of belief in spirits and imaginations of the immortal soul" (my translation). Petersen's (2012) study of Danish adolescents' use of American fictional drama to engage with religious issues shows that young people may distance themselves strongly from traditional religion, the national Protestant church, while at the same time ascribe importance to various forms of supernatural imagery in popular culture. Hjarvard's (2013) surveys of religion in Denmark demonstrate that various media have become important sources of knowledge about religion, and popular media narratives like Dan Brown's Da Vinci Code have encouraged interest in religious issues at the same time as readers and viewers ascribe authority to Dan Brown's criticism of the Catholic Church. Clark (2011) proposes that cultural authority is increasingly established through 'consensus-based interpretative authority': "The process of mediatization means that collective uses of media push popularity and consensus above other criteria of cultural authority" (Clark, 2011: 120). The notion of consensus-based authority does not imply that everybody must agree but suggests that authority is established within a particular media circuit in which an authoritative person must be seen to articulate widely appreciated and acceptable views of the world. In other words, authority rests not only on recognition by 'followers' but also on the authority's sensibility and attentiveness to its followers' emotions, perceptions, and practices.

An important problem in discussing Weber's notions of authority in relation to modern media (mass media as well as social network media) is that he was concerned with the exercise of legitimate types of domination within institutionalized hierarchies serving particular social functions, such as the feudal household, the modern bureaucracy, and the church. Thus, Weberian forms of authority concern the legitimacy of leaders to act on behalf of a collectivity and the ability to get subordinates to act in compliance with the person in authority. The exercise of authority in this sense has direct and important consequences for both individuals and the social subsystem in question. This does not apply to the same extent in the case of modern mediated communication. The use of mass media and social network media is predominantly a voluntary activity, often with no explicit function apart from the communication itself, and participants are free to come and go, to agree or disagree. All forms of authority involve some element of voluntary compliance, as Weber himself states; otherwise authority would be synonymous with the simple use of force. But matter of degree also makes a difference: It is clearly less obligatory to watch an entertainment show or post a comment on a blog than it is to follow the instructions of one's boss. 
In the context of media, authority concerns the legitimacy of individuals or particular media organizations to assert arguments and viewpoints about a particular social or cultural domain. The ascription of authority to particular voices or media organizations may have important consequences for individuals as well as society in the long run, but authority in the media is (with a few exceptions) not immediately concerned with the execution of orders. Instead, the media allow users to ascribe authority on an individual and voluntary basis. The process of building authority in the media is nevertheless a collective practice in the sense that participation by others becomes a token of authority: The accumulated actions of reading, watching, liking, following, sharing, and commenting become indexes of the popularity of the media or communicator in question and his or her ability to articulate the sentiments and perceptions of a given community of people. In this way, authority is also dependent on the various logics of connectivity identified by Dijck (2013) in various social network media: popularity, hierarchical ranking, personalized recommendations, etc. Not only in the case of mass media, but also social network media, authority is reflected by the ability to command an audience.

The particularities of the media and genres in question influence the ways in which popularity and ability to articulate perceptions and sentiments of a particular group of media users are articulated. Different rules apply to comedy shows than to blogging. The important point is that when media become a prominent source of information and experiences about religious issues, the various logics of the media influence the ways in which religion is represented and condition the ways in which authority to speak about these issues is constructed. The individualistic and popular basis of authority seems more prevalent in the cultural field than in the political field. When religion is discussed in factual and journalistic genres such as news, current affairs, and political debates, a rational kind of authority tends to dominate, often with the effect of marginalizing the authority of religious actors and viewpoints. Studying the mainstream press' coverage of religion, Christensen (2012) documents that news media primarily tend to focus on religion when religious actors appear to be out-of-sync with the general (secular) values of society. Broberg's (2013) study of the role of religious actors on the opinion pages of a major Swedish daily, Aftonbladet, suggests that religious arguments exert little authority, and religious actors tend to use secular arguments, "for example by reference to science, humanism, or modern values of freedom and equality" (Broberg, 2013: 45). Within the realm of factual and journalistic genres, authority is also dependent on the ability to articulate viewpoints that resonate with commonly held beliefs, but in such contexts a fundamental consensus concerning deliberative rationality and secular ideals has been institutionalized, leaving less room for establishing authority with reference to religious sentiments and beliefs. The conflict over the Mohammed cartoons is an extreme yet paradigmatic example of this media dynamic. The initial publication of the Mohammed cartoons in the Danish newspaper Jyllands-Posten gradually turned into a global conflict, rallying news media in favor of Western democratic values and free speech against Islamic extremism (Hjarvard 2010).

\section{Mediatization, Modernity, and Religion}

The growing visibility of religion both globally and in Western societies from the 1990s and onwards spurred for good reason -increased scholarly interest in religion. For some scholars of religion, this development was

used to declare - in some cases triumphantly (e.g. Stark, 1999) - the death of the secularization thesis, and this 
stance has gradually developed into a new orthodoxy in the sociology of religion. Just as it was popular in the 1950s and 1960s to speak of the secularization of modern society, it has become self-evident today to speak of the death of secularization and the resurgence of religion.

The problem with this academic swing of the pendulum is the lack of empirical evidence to support it. The major comparative surveys charting religious beliefs and practices around the world do not register a major upheaval in religion but rather a slow continuous decline in religious belief and practices. Norris and Inglehart (2004) and Inglehart and Welzel (2005) report a continued connection between indicators of modernization and decline of religious belief and practices, not only in Europe but in many other places as well. A recent study of religion in the USA, which is often suggested as the country to falsify the connection between modernity and secularism, reports that the group of religiously unaffiliated continues to grow and today makes up one third of all adults under the age of 30 (Pew Research Center, 2012). Habermas (2008: 19) also states that "the data collected globally still provide surprisingly robust support for the defenders of the secularization thesis." This in no way implies that religion will eventually disappear, but it does entail that modernity, including its mediatized conditions, influences the forms of religious imaginations and practices that will prevail. As such, secularization theory addresses the changing conditions of religion in modern society, not the disappearance of religion (cf. Dobbelaere, 2002).

These general observations are important for understanding mediatized religion because the growing visibility of religion in media is often taken as superficial evidence of a general re-sacralization of society. Instead, I will argue, the presence of religion in various media reflects a much more multi-facetted development in which religion is evoked, contested, and subject to transformation. The changing authority of religion in society is among other factors - influenced by general processes of mediatization. Changing media structures challenge existing forms of religious authority at the same time as they allow new forms of authority to emerge - forms that have a more individualized and temporary character and rely on popular cultural forms. Weber's (1978) three forms of authority still play important roles, but they are being gradually challenged by new ways of providing legitimacy to religious imaginations, practices, and objects.

\section{References}

Anderson B (1994) Imagined Communities, Reflections on the Origin and Spread of Nationalism. London: Verso.

Berger PL (1999) The Desecularization of the World: A Global Overview. In: Berger PL (ed) The Desecularization of the World: Resurgent Religion and World Politics. Washington D.C.: Ethics and Public Policy Center.

Billig M (1995) Banal Nationalism. London: Sage.

Broberg M (2013) Religious Actors on the Debate Pages of Aftonbladet. Master Thesis, Uppsala University. Available at: http://www.diva-portal.org/smash/get/diva2:655186/FULLTEXT01.pdf (accessed 27 January 2015). 
Campbell H (2007) Who's Got the Power? Religious Authority and the Internet. Journal of Computer-Mediated Communication 12(3): 1043-1062.

Carey J (1989) Communication as Culture: Essays on Media and Society. Winchester, MA: Unwin Hyman.

Christensen HR (2012) Mediatization, Deprivatization, and Vicarious Religion. In: Hjarvard S and Lövheim M (eds) Mediatization and Religion: Nordic Perspectives. Gothenburg: Nordicom, 63-78.

Clark LS (2008) Religion, philosophy, and convergence culture online: ABC's Lost as a study of the processes of mediatization. Northern Lights 6(1): 143-163.

Clark LS (2011) Religion and Authority in a Remix Culture. How a Late Night TV Host Became an Authority on Religion. In: Lynch G, Mitchell J, and Strhan A (eds) Religion, Media and Culture: A Reader. London: Taylor and Francis, 111-121.

Dijck, Jv (2013) The Culture of Connectivity. A Critical History of Social Media. Oxford: Oxford University Press. Dobbelaere K (2002) Secularization: An Analysis at Three Levels. New York: Peter Lang.

Endsjø D $\varnothing$, Lied LI (2011) Det folk vil ha: Religion og populærkultur [What People Want: Religion and Popular Culture]. Oslo: Universitetsforlaget.

Fischer-Nielsen P (2012) The Internet Mediatization of Religion and Church. In: Hjarvard S and Lövheim M (eds) Mediatization and Religion: Nordic Perspectives. Gothenburg: Nordicom, 63-78.

Habermas J (2008) Notes on Post-Secular Society. New Perspectives Quarterly 25(4):17-29.

Hepp A, Hjarvard S, and Lundby K (2010) Mediatization - Empirical Perspectives: An Introduction to a Special Issue. Communications 35(3): 223-228

Herbert D (2011) Why has Religion Gone Public Again? Towards a Theory of Media and Religious RePublicization. In: Lynch G, Mitchell J, and Strhan A (eds) Religion, Media and Culture: A Reader. London: Taylor and Francis, 89-97.

Hjarvard S (2009) Soft Individualism: Media and the Changing Social Character. In: Lundby K (ed) Mediatization: Concept, Changes, Consequences. New York: Peter Lang, pp. 159-177.

Hjarvard, S (2010) Die Mediendynamik der Mohammed-Karikaturen-Krisen. In: Hepp A, Höhn M, and Wimmer J (eds) Medienkultur im Wandel. Konstanz: UVK Verlagsgesellschaft, 169-180.

Hjarvard S (2011) The Mediatization of Religion: Theorising Religion, Media and Social Change. Culture and Religion 12(2): 119-135.

Hjarvard S, Lövheim M (eds) (2012) Mediatization and Religion: Nordic Perspectives. Gothenburg: Nordicom. Hjarvard S (2013) The Mediatization of Culture and Society. London: Routledge. 
Hoover SM (2006) Religion in the Media Age. London: Routledge.

Inglehart R, Welzel C (2005) Modernization, Cultural Change, and Democracy. Cambridge: Cambridge University Press.

Lövheim M (2012) A Voice of Their Own. Young Muslim Women, Blogs, and Religion. In: Hjarvard S and Lövheim M (eds) Mediatization and Religion: Nordic Perspectives. Gothenburg: Nordicom, 129-145.

Martino LMS (2013) The Mediatization of Religion, When Faith Rocks. Farnham: Ashgate.

Meyer B and Moors A (2007) Introduction. In: Meyer B and Moors A (eds) Religion, media, and the public sphere, Bloomington: Indiana University Press, 1-25.

Meyrowitz J (1993) Images of Media: Hidden Ferment - and Harmony - in the Field. Journal of Communication 43(3): 55-66.

Norris P, Inglehart R (2004) Sacred and Secular: Religion and Politics Worldwide. Cambridge: Cambridge University Press.

Petersen LN (2012) Danish Twilight Fandom. Transformative Processes of Religion. In: Hjarvard S and Lövheim M (eds) Mediatization and Religion: Nordic Perspectives. Gothenburg: Nordicom, 163-182.

Pew Research Center (2012) "Nones" on the Rise: One-in-Five Adults Have no Religious Affiliation. The Pew Forum on Religion and Public Life. Available at: http://www.pewforum.org/2012/10/09/nones-on-the-rise/ (accessed 14 May 2014).

Stark R (1999) Secularization, R.I.P. Sociology of Religion 60(3): 249-273.

Weber M (1978) Economy and Society: An Outline of Interpretive Sociology. Berkeley, CA: University of California Press.

The research for this article was partly supported by the research project "The Mediatization of Culture: The Challenge of New Media", funded by The Danish Research Council for Culture and Communication (FKK). 